\title{
The negative and positive pressure system of natural balanced ventilation
}

\author{
Tomasz Gaczot \\ tgaczol@pk.edu.pl | (1) http://orcid.org/0000-0002-1360-0035 \\ Institute of Construction Design, Faculty of Architecture, \\ Cracow University of Technology
}

Scientific Editor: Marek Piekarczyk, Cracow University of Technology Technical Editor: Aleksandra Urzędowska, Cracow University of Technology Press Language Editors: Tim Churcher, Big Picture Typesetting: Matgorzata Murat-Drożyńska, Cracow University of Technology Press

Received: February 7, 2020

Accepted: July 23, 2020

Copyright: $\odot 2020$ Gaczot. This is an open access article distributed under the terms of the Creative Commons Attribution License, which permits unrestricted use, distribution, and reproduction in any medium, provided the original author and source are credited.

Data Availability Statement: All relevant data are within the paper and its Supporting Information files.

Competing interests: The authors have declared that no competing interests exist.

Citation: Gaczot, T. (2020). The negative and positive pressure system of natural balanced ventilation. Technical Transactions, e2020026. https://doi. org/10.37705/TechTrans/e2020026

\begin{abstract}
This paper discusses the results of research conducted with the Ansys Fluent programme on the air flow through natural ventilation supply and exhaust ducts of rooms located on the ground and upper floor of a building. A scenario with air inflow to a room through an air intake located on the basement floor level was selected for the tests. All simulations were performed for outdoor temperatures of $+3,+12$, and $-15^{\circ} \mathrm{C}$ (simulations run for an outdoor air temperature of $+12^{\circ} \mathrm{C}$ are discussed in detail). The temperature inside the room is $+20^{\circ} \mathrm{C}$, i.e. at the minimum temperature level for thermal comfort. The simulations address such issues as the pressure system inside the room and in the exhaust duct, the distribution of air temperature in the room and the vector direction of airflow through the supply and exhaust ducts.
\end{abstract}

Keywords: positive pressure, negative pressure, supply, exhaust, exchange rate, air stream 


\section{Introduction}

Naturalventilation is the process of airexchangingas a result of pressure differences. It continuously takes place through ventilation ducts. It is the most commonly used method of providing room ventilation and is both old and well proven. Design errors result in the lack of effective operation of gravity ventilation, one of the most common errors being the selection of an exhaust duct with an inappropriate cross sectional area in relation to its height. The standard requirements concerning the need to ensure an adequate air exchange rate or airflow rate measured in $\mathrm{m} 3 / \mathrm{s}$ are repeatedly ignored. As a result of such negligence, there are disparate ventilation effects in rooms located on different floors.

Currently conducted construction works consisting of the thermal modernisation of buildings result in limiting the inflow of an appropriate airstream to rooms. This is the cause of problems relating to malfunctioning natural ventilation that operates periodically and with variable performance (Gtadyszewska-Fiedoruk, Zhelykh, Pushchinskyi, 2019). The majority of existing residential buildings in Poland are built on the basis of a natural ventilation system. The PN-83/B-03430 requirements state that new buildings up to nine floors in height can also be equipped with a natural ventilation system. How then can systems for such height-differentiated residential buildings be designed correctly? (Gasiński, 2019; Geetha, Velraj, 2012). The author hopes that the presented idea will help to minimise problems relating to the proper functioning of natural ventilation, which is responsible for the health and well-being of people in the building, as well as for obtaining good microclimatic parameters, e.g. humidity, temperature and proper negative air ionisation (JędrzejewskaŚcibak, 1996; OMI, 2002; Gaczot, 2018a). The appropriate technical condition of the envelope and other elements enable the avoidance of dampness and mould formation; these are other effects of a well-functioning natural ventilation system (Jędrzejewska-Ścibak, Sowa, Zawada, 1992; Jędrzejewska-Ścibak, Sowa, 2000); the proposed solution can be widely used in our country to achieve these objectives. The solution does not require large financial outlay or the use of complex and expensive ventilation equipment.

\subsection{Operating principle}

A room located on the low floor of the building is considered as the first case. It is usually equipped with a long natural ventilation duct that runs vertically through the whole height of the building. Negative pressure occurs in the room and this phenomenon is intensified when the airflow is limited. This happens because the air that fills the air space of the room is continuously sucked in and out through a high-exhaust natural ventilation duct. Whether the outdoor air mass is brought from the air intake to the ventilated room via the same walledin duct (if it goes down to the level of the air intake) or via a newly designed duct, the pressure difference is compensated. The inflow and outflow occurs with the same air stream, regardless of the fact that the room is tightly closed and the building is thermo-modernised. The necessary condition for such an exchange is the separation of the supply and exhaust ducts. If the system is to operate on the basis of the existing natural ventilation duct, the duct inlet and outlet must be separated (walled in). However, if the existing natural ventilation duct begins only at the level of the ventilated floor, a new supply air duct must be led to it. A room situated on a high floor of the building is considered in the second case. It is usually equipped with a short, vertical natural ventilation duct. Negative pressure occurs in the room and this phenomenon is intensified when the airflow is limited. This is because the air filling the room air space is constantly sucked in and should be discharged outside. Whether the outdoor air mass is brought from the intake to the ventilated room with the same walled-in duct (if it goes down to the level of air intake) or via a newly designed duct, there is an increased gravitational inflow of air into the room. The inflow and outflow 
occurs with the same airstream. In this way, rooms located on different floors are equally ventilated regardless of the difference in the height of the exhaust duct, assuming that the cross-sectional dimensions are the same.

When designing a negative or positive pressure natural ventilation system, proper air supply to the building must be ensured. An air intake is used for this purpose, which may be located on the northern, eastern or north-eastern side, e.g. in the basement or ground floor of the building (Form \& Orientation). The intake should be designed in the immediate vicinity of vertical natural ventilation ducts. The room intended for it should be heated (recommended air temperature ranging from $16^{\circ} \mathrm{C}$ to $18^{\circ} \mathrm{C}$ and relative humidity from $40 \%$ to $60 \%$ ), periodically cleaned and have all the walls and floors made of washable materials. Its surface area should not be less than $2.0 \mathrm{~m}^{2}$ and its height should be at least $2.2 \mathrm{~m}$ (these values are based on common functional needs). The air intake vent must be installed at a height of at least 100 centimetres from ground level and fitted with a filter to prevent dust particles, dirt and other contaminants from entering the air intake. The cross-sectional area of the air inlet duct to the air intake must be at least twice as large as the sum of the cross-sectional areas of the air supply ducts delivering air from the air intake to individual utility rooms (Gaczot, 2018b; PN-83/B-03430). This requirement is due to the resistances occurring during the flow of air masses through the filter and its movement, which should not exceed $0.5 \mathrm{~m} / \mathrm{s}$ in closed rooms and its optimal value is 0.15 $\mathrm{m} / \mathrm{s}$ (the Polish standards define the airflow velocity at the level of $0.7 \mathrm{~m} / \mathrm{s}$ in closed rooms) (Strzeszewski, 2003; Gaczot, 2007). The air intake can also be connected to an underground air storage tank located below the ground freezing level. The air used for ventilation is preheated in the storage tank, which results in savings resulting from minimal heat loss owing to the exchange of air in the rooms. Detailed regulations regarding the requirements for air intakes and exhaust vents can be found in Journal of Laws of 2013 item 926: "Regulation of the Minister of Transport, Construction and Maritime Economy of 5 July 2013, amending the Regulation on the technical conditions to be met by buildings and their location" (JL, 2013).

\section{Methodology}

The adopted research method consisted of studying literature that included peerreviewed journals, peer-reviewed conference proceedings and reports available on the Internet and in books. However, the research method consisted primarily in checking the simulation of airflow through the air intake, the room and the duct in ANSYS FLUENT computer software. The results for individual examples related to differences in the heights of ventilation ducts, the method of air supply and, most importantly, the output parameters of the outdoor air temperature and the required indoor temperature of the room have been developed. The flow velocity, temperature distribution in individual elements of the system, as well as pressure distribution and the manner of vector airflow through the room have been checked, thus providing an answer to the question of whether air masses mix in the examined room volume.

This issue has also been presented in the form of a survey to second year students of the Faculty of Architecture at Cracow University of Technology and has been met with great interest. Their task involved drawing the theoretical airflow direction on the attached diagrams and indicating the positive or negative pressure zones with a plus or minus sign. A majority of students completed the task with understanding (Gaczot, Celadyn, 2019). 


\section{Case study}

In the two considered cases (i.e. for a room located on the ground floor and the upper floor ventilated by means of an air intake situated on the level of the basement floor), the value of the outdoor air temperature has been assumed at the level of $+12^{\circ} \mathrm{C}$.

\subsection{Case 1}

The first case presents a room on the ground floor with an area of $16.0 \mathrm{~m}^{2}$ and a volume of $43.2 \mathrm{~m}^{3}$, ventilated by means of natural balanced ventilation ducts with a cross section of $14 \times 14 \mathrm{~cm}\left(196 \mathrm{~cm}^{2}\right)$, enlarged to $14 \times 21 \mathrm{~cm}$ in the inlet part. The air inflow is provided by a duct from an air intake located in the basement of the building. The air intake is a room with an area of $4.0 \mathrm{~m}^{2}$ and a volume of $10.0 \mathrm{~m}^{3}$. The outdoor air is at a temperature of $+12^{\circ} \mathrm{C}$ flows into the intake through an $14 \times 14 \mathrm{~cm}$ opening. The walls and floor in the intake room are finished with washable surfaces that are easy to clean and with a heater that in this case heats the incoming outdoor air. The temperature of the heater in the air intake is $+20^{\circ} \mathrm{C}$. The heated air is supplied from the intake to the living quarter through a $60-\mathrm{cm}$-long air duct with a cross section of $196 \mathrm{~cm}^{2}$. The living quarter located on the ground floor of the building has a $210 \times 150 \mathrm{~cm}$ window opening and a $210 \times 70 \mathrm{~cm}$ heater with the required temperature of $+50^{\circ} \mathrm{C}$ below it. The aforementioned required heater temperatures have been chosen so that in each case, the indoor room temperature is maintained at $+20^{\circ} \mathrm{C}$, which is considered to be the minimum thermal comfort level. The designed window is tightly closed (no infiltration through window frames). The air is discharged from the ventilated room to the outside through a $12.0-\mathrm{m}$-long exhaust duct. The geometry of the examined case is shown in Fig. 1.

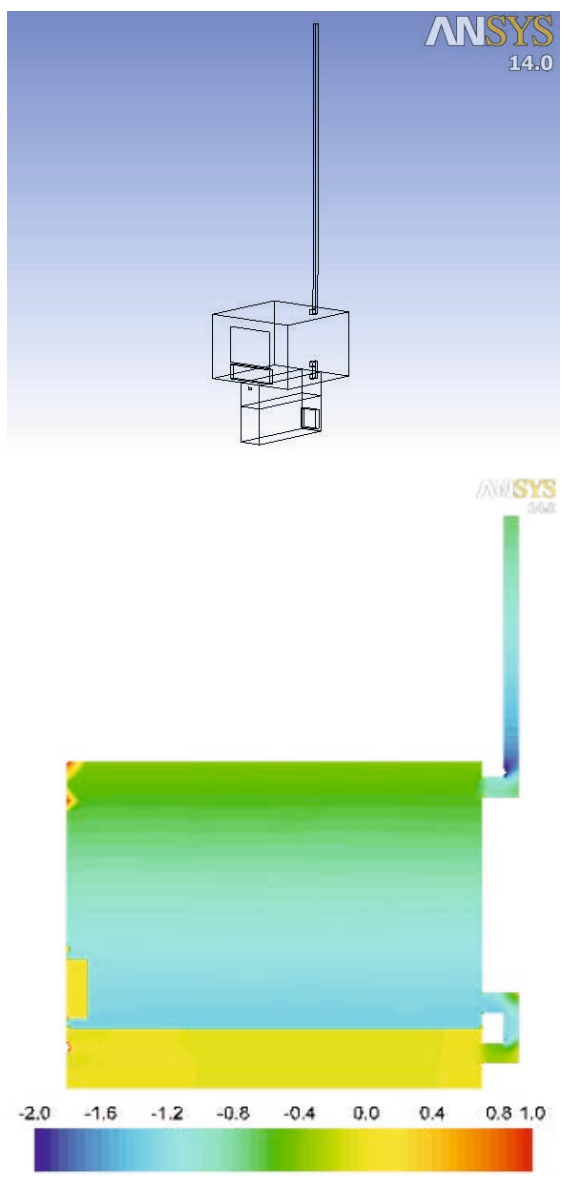

Fig. 1. $\leftarrow$ Axonometric drawing of the model - Case 1

Fig. 2. $\downarrow$ Pressure distribution in the longitudinal section; diagram of the pressure prevailing in the exhaust duct $(\mathrm{Pa})$

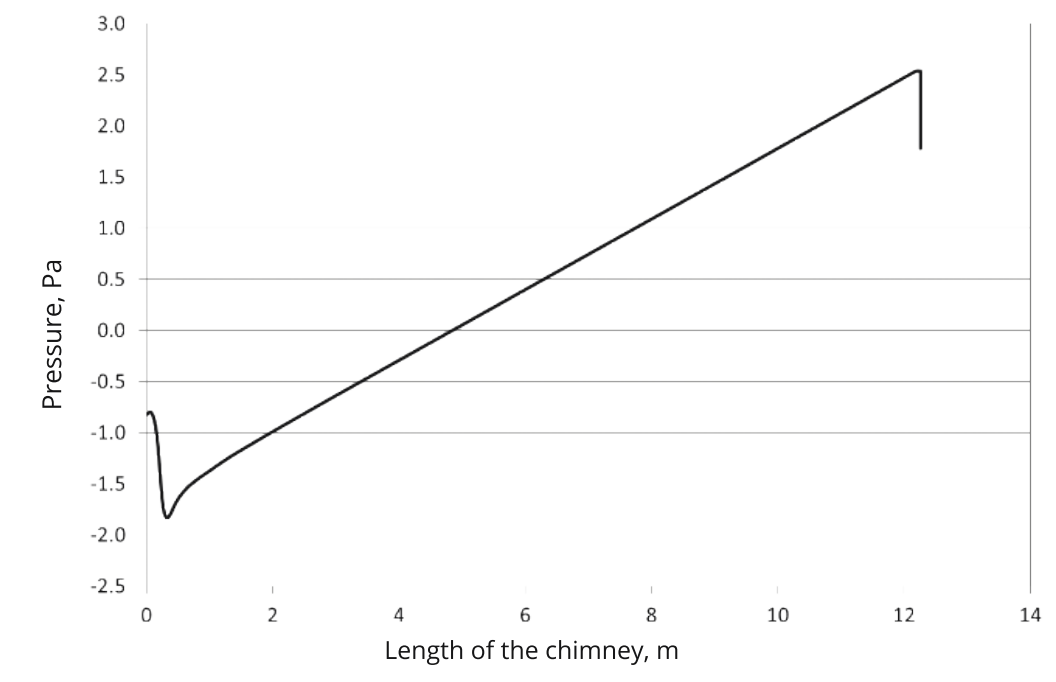


Fig. 3. The air velocity in the room $(\mathrm{m} / \mathrm{s})$ - longitudinal and cross section
During computer simulations with the Ansys Fluent software, the following tests were conducted:

- Air pressure distribution (the given pressure diagram is measured in $\mathrm{Pa}$ ) was tested in the living quarter and in the exhaust natural ventilation duct (vertical section through the centre of the room and the exhaust ventilation duct), see Fig. 2.

Conclusions:

There is negative pressure in the ventilated room and a slight positive pressure in the air intake in comparison to the prevailing external pressure. In the longitudinal section, there is a clear increase in pressure in the upper part of the room. Initially, a pressure drop is visible in the exhaust chimney, but it increases along the length of the exhaust chimney.

- The vector direction of the airflow $(\mathrm{m} / \mathrm{s})$ was tested in the longitudinal section of the room and supply and exhaust ducts as well as in the cross section, see Fig. 3.
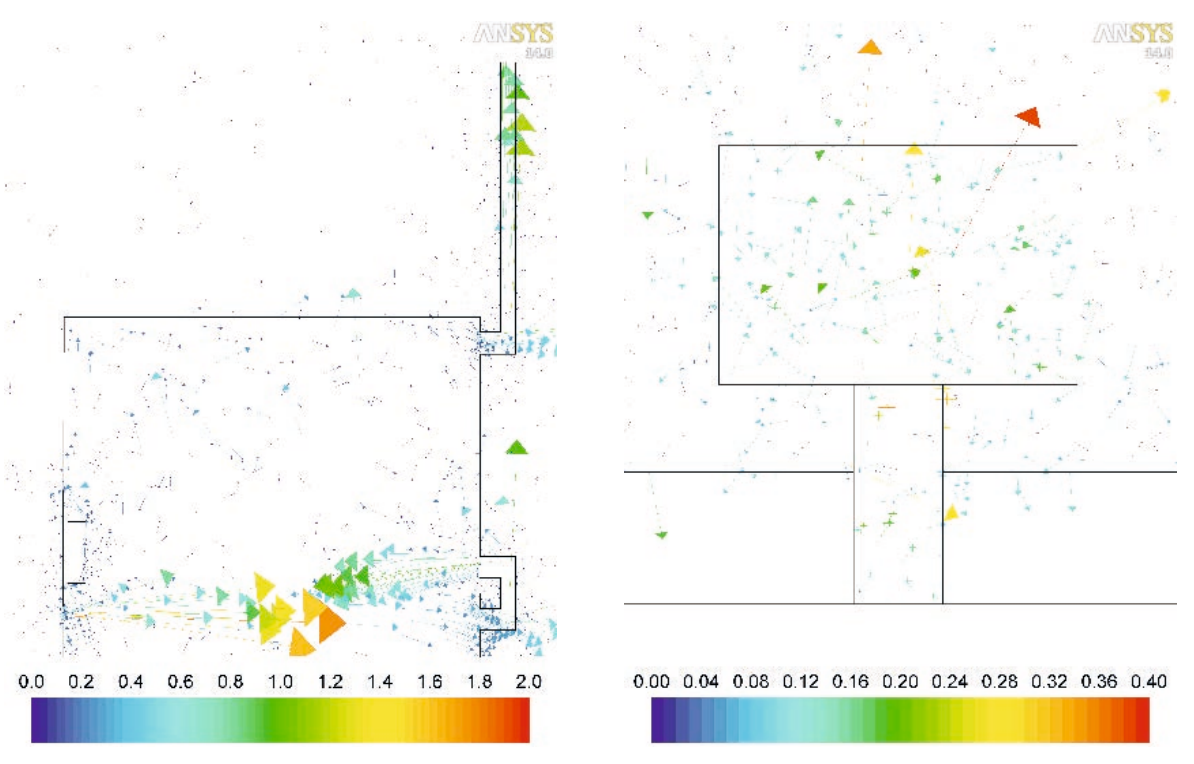

$\begin{array}{lllllllllll}0.00 & 0.04 & 0.08 & 0.12 & 0.16 & 0.20 & 0.24 & 0.28 & 0.32 & 0.36 & 0.40\end{array}$

Conclusions:

An increase in air movement of around $1 \mathrm{~m} / \mathrm{s}$ can be observed only in the supply and exhaust area and near the heater. The air velocity in the middle of the room is around $0.3 \mathrm{~m} / \mathrm{s}$. The air particles become mixed in the room.

- The distribution of air mass temperatures $\left({ }^{\circ} \mathrm{C}\right)$ in the longitudinal section and cross section of the living quarter, the longitudinal section of the air intake, the living quarter and supply and exhaust chimneys were tested. Figure 4 presents a diagram showing the air temperature distribution in the chimney $\left({ }^{\circ} \mathrm{C}\right)$.

Conclusions:

The temperature ranges from $+15^{\circ} \mathrm{C}$ in the lower part of the room to around $+22^{\circ} \mathrm{C}$ in the upper part of the room. The average indoor temperature is $+20^{\circ} \mathrm{C}$. The air temperature in the exhaust chimney decreases slightly as the length of the chimney increases and remains at approximately $+20.19^{\circ} \mathrm{C}$. 


\section{口:: technical

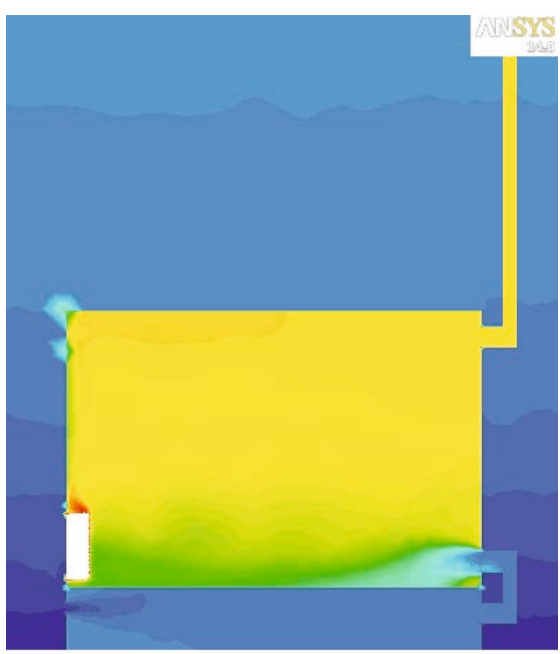

$\begin{array}{lllllllll}10 & 12 & 14 & 16 & 18 & 20 & 22 & 24 & 25\end{array}$

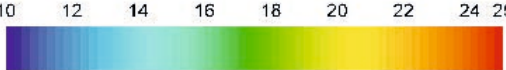

The outdoor air $\left(+12^{\circ} \mathrm{C}\right)$ heated to a temperature of around $+14^{\circ} \mathrm{C}$ with a heater located in the lower zone goes through the supply duct to the living quarters. According to computer calculations, the ventilation air stream is $0.0221 \mathrm{~kg} / \mathrm{s}=66.3 \mathrm{m3} / \mathrm{h}$, which accounts for around 1.5 times the air exchange in the room.

\subsection{Case 2}

The second case presents a room on the upper floor with an area of $16.0 \mathrm{~m}^{2}$ and a volume of $43.2 \mathrm{~m}^{3}$, ventilated by means of natural balanced ventilation ducts with a cross section of $14 \times 14 \mathrm{~cm}\left(196 \mathrm{~cm}^{2}\right)$, enlarged to $14 \times 21 \mathrm{~cm}$ in the inlet part. The air inflow is provided by a duct from an air intake located in the basement part of the building. The air intake is a room with an area of $4.0 \mathrm{~m}^{2}$ and a volume of $10.0 \mathrm{~m}^{3}$. The outdoor air at a temperature of $+3^{\circ} \mathrm{C}$ flows into the intake through a $14 \times 14 \mathrm{~cm}$ opening. The walls and floor in the intake room are finished with washable surfaces that are easy to clean and there is a heater that in this case heats the incoming outdoor air. The temperature of the heater in the air intake is $+20^{\circ} \mathrm{C}$. The heated air is supplied from the intake to the living quarter through a 9-metre-long air duct with a cross section of $196 \mathrm{~cm}^{2}$. The living quarter located on the upper floor of the building has a $210 \times 150 \mathrm{~cm}$ window opening and a $210 \times 70 \mathrm{~cm}$ heater with the required temperature of $+45^{\circ} \mathrm{C}$ below it. The aforementioned required heater temperatures were chosen so that in each case, the indoor room temperature is maintained at $+20^{\circ} \mathrm{C}$, which is considered to be the minimum thermal comfort level. The designed window is tightly closed in order that there is no infiltration of air through the window frames. The air is discharged from the ventilated room to the outside through a 3.0-m-long exhaust duct. The geometry of the examined case is shown in Fig. 5.
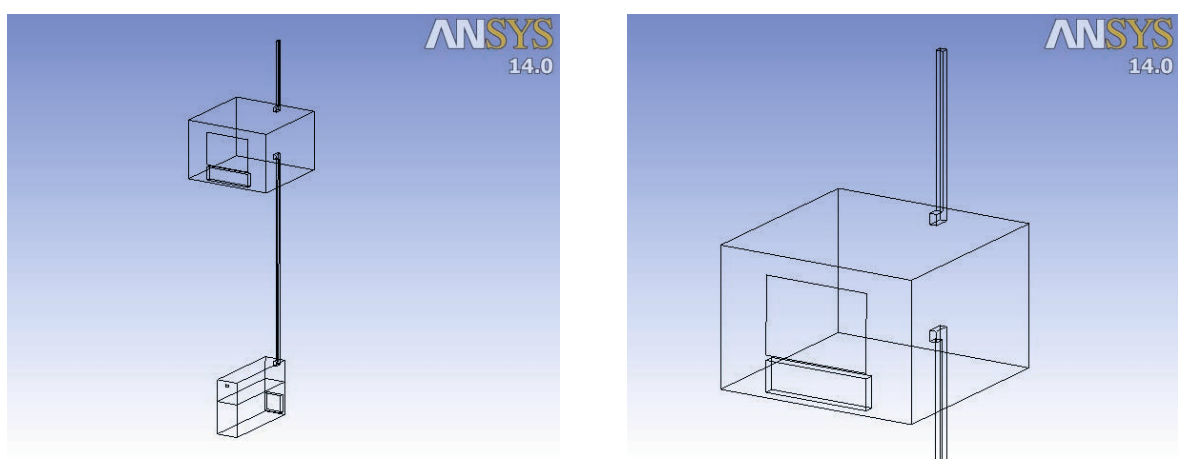

Fig. 4. Air temperature distribution $\left({ }^{\circ} \mathrm{C}\right)$ - longitudinal and cross section
Fig. 5. Axonometric drawing of the model - Case 2 


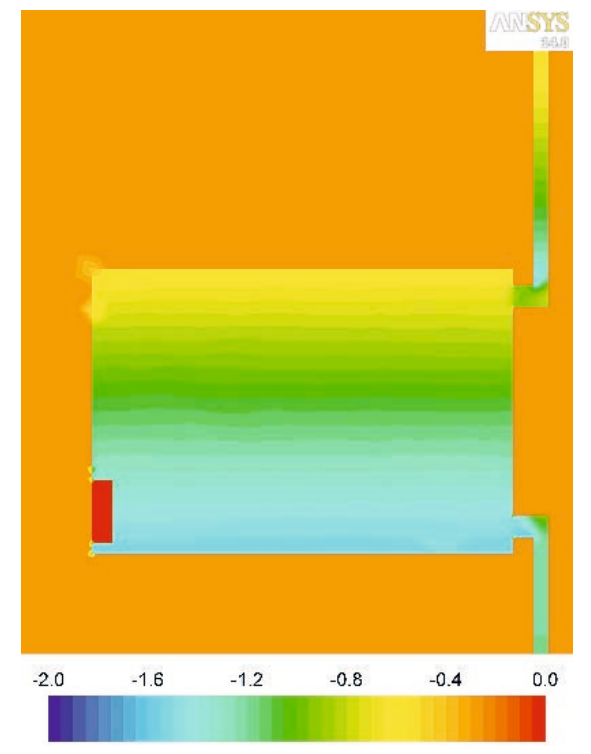

Fig. 6. Pressure distribution in the longitudinal section; diagram of the pressure prevailing in the exhaust duct $(\mathrm{Pa})$
During computer simulations with the Ansys Fluent software, the following tests were conducted:

- Air pressure distribution was tested (the given pressure diagram is measured in $\mathrm{Pa}$ ) in the living quarter and in the exhaust natural ventilation duct (vertical section through the centre of the room and the exhaust ventilation duct), see Fig. 6.

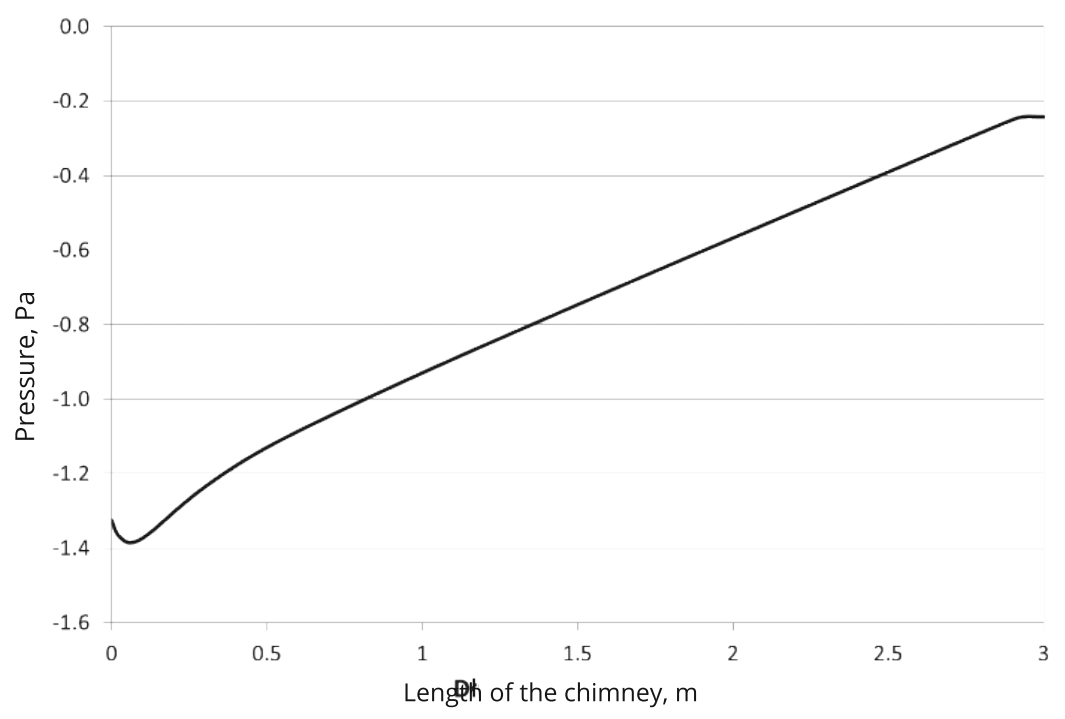

Conclusions:

There is negative pressure in the ventilated room and a slight positive pressure in the air intake in comparison to the prevailing external pressure. In the longitudinal section, there is a clear increase in pressure in the upper part of the room. Initially, a pressure drop is visible in the exhaust chimney, but it increases along the length of the exhaust chimney.

- The vector direction of the airflow (m/s) was tested in the longitudinal section of the room and supply and exhaust ducts as well as in the cross section, see Fig. 7.

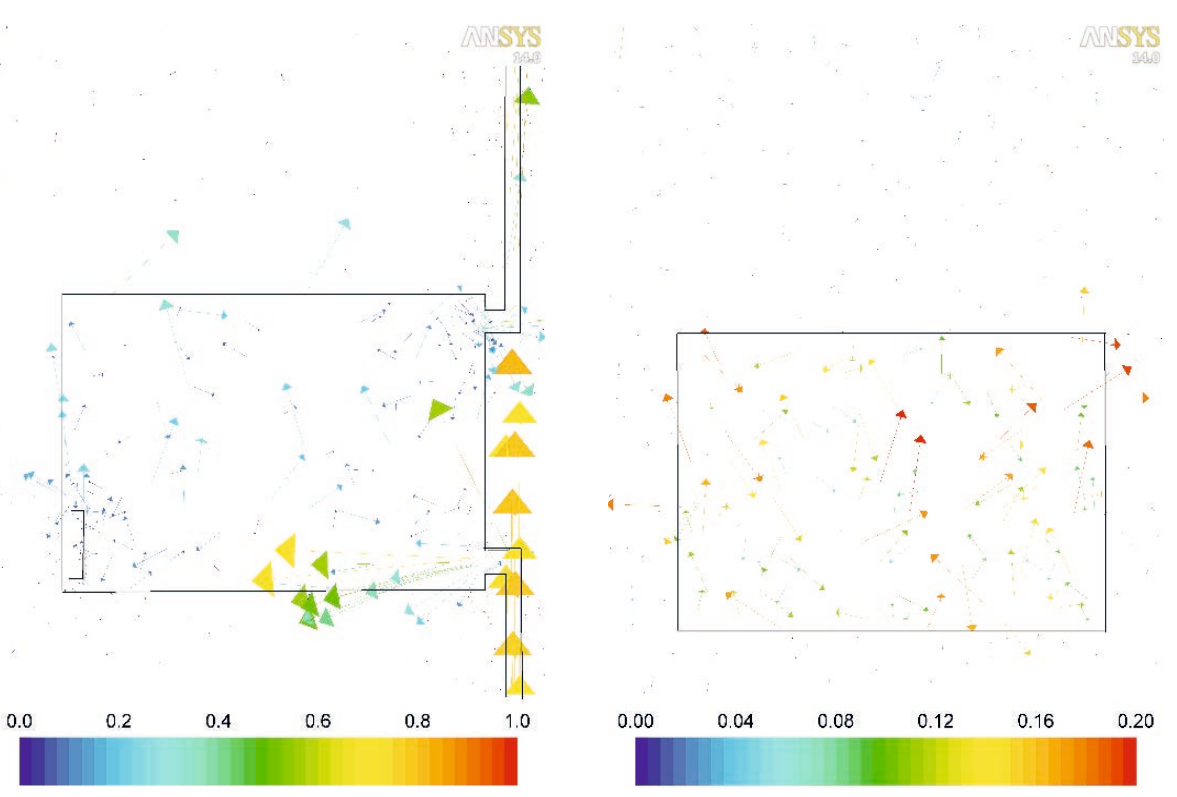

Fig. 7. The air velocity in the room $(\mathrm{m} / \mathrm{s})$ - longitudinal and cross section 


\section{::: technical

Conclusions:

An increased air movement of around $0.8 \mathrm{~m} / \mathrm{s}$ can be observed only in the air supply area. In the exhaust air duct and near the heater, it is around $0.4 \mathrm{~m} / \mathrm{s}$. In the middle of the room, the air velocity is around 0.2 $\mathrm{m} / \mathrm{s}$. The air particles become mixed.

- The distribution of air masses temperature $\left({ }^{\circ} \mathrm{C}\right)$ was tested in the longitudinal section and cross section of the living quarter, the longitudinal section of the air intake, the living quarter and the supply and exhaust chimneys. The air temperature $\left({ }^{\circ} \mathrm{C}\right)$ distribution in the chimney is shown in Fig. 8.
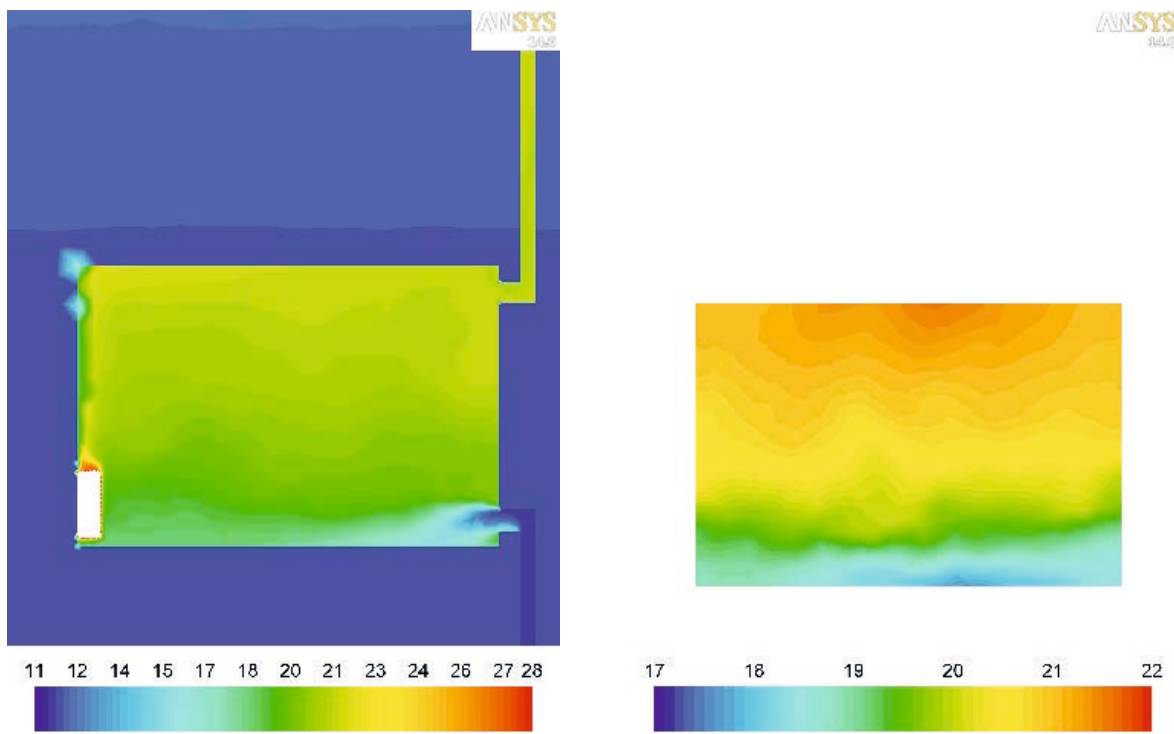

Conclusions:

The temperature ranges from $15^{\circ} \mathrm{C}$ in the lower part of the room to around $22^{\circ} \mathrm{C}$ in its upper part. The average indoor temperature is $+20^{\circ} \mathrm{C}$. The temperature of the air in the exhaust chimney initially increases slightly, then decreases and then increases again as the length of the chimney increases and remains at around $20.21^{\circ} \mathrm{C}$.

The outdoor air $\left(+12^{\circ} \mathrm{C}\right)$ is heated to a temperature of around $+14^{\circ} \mathrm{C}$ in the intake air intake and is then additionally heated to a temperature of around $+16^{\circ} \mathrm{C}$ with the heater placed in the lower zone, it flows through the supply duct to the living quarter. According to computer calculations, the ventilation air stream is $0.0171 \mathrm{~kg} / \mathrm{s}=51.3 \mathrm{~m} 3 / \mathrm{h}$, which accounts for around 1.2 times the air exchange in the room.

\section{Discussion}

The proposed solution yields the expected positive results in terms of air exchange rate as well as temperatures and pressures prevailing in the examined room and ventilation duct. The design of the air intake ensures appropriate parameters and, above all, ventilating the room with pre-heated air masses rather than with cold air, as is the case with the use of window vents or unsealed windows. As with the two cases presented in the article (cases $B$ in the table), tests for outdoor temperatures of $+3^{\circ} \mathrm{C}$ (cases $\mathrm{A}$ in the table) and $-15^{\circ} \mathrm{C}$ (cases $C$ in the table) were conducted.

Without fail, it can be argued that the results confirm the initial assumptions regarding the minimum required airstreams and thus the air exchange rate. The author believes that even better results can be achieved when using
Fig. 8. Air temperature distribution $\left({ }^{\circ} \mathrm{C}\right)$ - ventilation air temperature distribution $\left({ }^{\circ} \mathrm{C}\right)$ in a 3 m exhaust duct 
so-called solar chimneys instead of ordinary exhaust chimneys. Owing to the glass cubic capacity in the former ones, the temperature of the air increases, thus intensifying its flow in the vertical exhaust duct and increasing the exchange rate (Arzpeyma et. al, 2020; Behling, 1996).

Table 1. Summary of the results from the tested schemes for temperatures: $+12^{\circ} \mathrm{C},+3^{\circ} \mathrm{C},-15^{\circ} \mathrm{C}$

\begin{tabular}{|c|c|c|c|c|c|}
\hline Case & $\begin{array}{c}\text { Outdoor air } \\
\text { temperature } \\
\text { [OC] }\end{array}$ & $\begin{array}{c}\text { Indoor air } \\
\text { temperature } \\
{[\mathrm{OC}]}\end{array}$ & $\begin{array}{l}\text { Temperature } \\
\text { of the heater } \\
\text { in the room [OC] }\end{array}$ & $\begin{array}{l}\text { Temperature } \\
\text { of the heater in } \\
\text { the intake [OC] }\end{array}$ & $\begin{array}{l}\text { Ventilation } \\
\text { airstream } \\
{[\mathrm{kg} / \mathrm{s}],\left[\mathrm{m}^{3} / \mathrm{h}\right]}\end{array}$ \\
\hline $\begin{array}{l}\text { A - ground } \\
\text { floor }\end{array}$ & $-15^{\circ} \mathrm{C}$ & $+20^{\circ} \mathrm{C}$ & $+45^{\circ} \mathrm{C}$ & $+90^{\circ} \mathrm{C}$ & $\begin{array}{l}0.0289 \mathrm{~kg} / \mathrm{s} \\
=86.7 \mathrm{~m}^{3} / \mathrm{h}\end{array}$ \\
\hline $\begin{array}{l}\text { A - upper } \\
\text { floor }\end{array}$ & $-15^{\circ} \mathrm{C}$ & $+20^{\circ} \mathrm{C}$ & $+80^{\circ} \mathrm{C}$ & $+90^{\circ} \mathrm{C}$ & $\begin{array}{l}0.0290 \mathrm{~kg} / \mathrm{s} \\
=87.0 \mathrm{~m}^{3} / \mathrm{h}\end{array}$ \\
\hline $\begin{array}{l}\text { B - ground } \\
\text { floor }\end{array}$ & $+12^{\circ} \mathrm{C}$ & $+20^{\circ} \mathrm{C}$ & $+50^{\circ} \mathrm{C}$ & $+20^{\circ} \mathrm{C}$ & $\begin{array}{l}0.0221 \mathrm{~kg} / \mathrm{s} \\
=66.3 \mathrm{~m}^{3} / \mathrm{h}\end{array}$ \\
\hline $\begin{array}{l}\text { B - upper } \\
\text { floor }\end{array}$ & $+12^{\circ} \mathrm{C}$ & $+20^{\circ} \mathrm{C}$ & $+45^{\circ} \mathrm{C}$ & $+20^{\circ} \mathrm{C}$ & $\begin{array}{l}0.0171 \mathrm{~kg} / \mathrm{s} \\
=51.3 \mathrm{~m}^{3} / \mathrm{h}\end{array}$ \\
\hline $\begin{array}{l}C \text { - ground } \\
\text { floor }\end{array}$ & $+3^{\circ} \mathrm{C}$ & $+20^{\circ} \mathrm{C}$ & $+35^{\circ} \mathrm{C}$ & $+70^{\circ} \mathrm{C}$ & $\begin{array}{l}0.0225 \mathrm{~kg} / \mathrm{s} \\
=67.5 \mathrm{~m}^{3} / \mathrm{h}\end{array}$ \\
\hline $\begin{array}{l}C \text { - upper } \\
\text { floor }\end{array}$ & $+3^{\circ} \mathrm{C}$ & $+20^{\circ} \mathrm{C}$ & $+65^{\circ} \mathrm{C}$ & $+90^{\circ} \mathrm{C}$ & $\begin{array}{l}0.0235 \mathrm{~kg} / \mathrm{s} \\
=70.5 \mathrm{~m}^{3} / \mathrm{h}\end{array}$ \\
\hline
\end{tabular}

\section{Final conclusions}

The pressure increase in the upper part of the room is clearly visible in all cases. Also, the temperature inside the room is maintained at a level of around $+20^{\circ} \mathrm{C}$ in all cases, which is the minimum temperature required for thermal comfort in the examined room. The vector movement of the airflow indicates that the air masses become mixed. In the second case analysed, the lowest ventilation airstream was obtained $\left(51.3 \mathrm{~m}^{3} / \mathrm{h}\right)$, which results from the length of a short 3-meter-long exhaust chimney. This is also influenced by the high outdoor air temperature, as the efficiency of the system increases along with decreases in outdoor air temperature. As can be seen from the above summary list, similar airstream values were obtained for individual examined cases (regardless of the location - ground floor, upper floor). The proposed solution of natural balanced ventilation ensures proper air exchange.

\section{References}

Arzpeyma, M., Mekhilef, S., Newaz, S., Horan, B., Seyedmahmoudian, M., Akram, N., Stojcevski, A., Solar chimney power plant and its correlation with ambient wind effect. Journal of Thermal Analysis and Calorimetry An International Forum for Thermal Studies. doi: 10.1007/s10973-01909065-z

Behling, S.S. (1996). Sol power. The evolution of solar architecture. Munich-New York: Prestel-Verlag.

Form \& Orientation. Retrieved from: https://nzeb.in/knowledge-centre/passivedesign/form-orientation/ (date of access: 7/02/2020).

Gaczot, T. (2007). Natural ventilation. Ventilation systems - selected examples. Czasopismo Techniczne 4-A, 63-70.

Gaczot, T. (2018a). Living quarters. A natural balanced ventilation system. Simulations part 1, E3S Web of Conferences, 49.

Gaczot, T. (2018b). Natural balanced ventilation. Simulations part 2. E3S Web of Conferences, 49. 
Gaczot, T., Celadyn, M. (2019). Basic drawings as primary material for teaching natural balanced ventilation systems. World Transactions on Engineering and Technology Education WIETE 17(4).

Gasiński, M. (2019). Określenie strumienia powietrza wentylacyjnego w budynkach mieszkalnych wielorodzinnych, Warunki techniczne.pl 2(28), 28-30.

Geetha, N. B., Velraj, R. (2012). Passive cooling methods for energy efficient buildings with and without thermal energy storage - A review. Energy Education Science and Technology Part A: Energy Science and Research, 29(2), 913-946.

Gtadyszewska-Fiedoruk, K., Zhelykh, V, Pushchinskyi, A. (2019). Analysis of Various Ventilation Systems Due to the Quality of Indoor Air in Educational Buildings, Proceedings 2019, 16, 29. doi:10.3390/proceedings2019016029

Jędrzejewska-Ścibak, T. (1996). Wentylacja a jakość powietrza wewnętrznego - doświadczenia i perspektywy. In: Materiaty zjazdowe XI Zjazdu Ogrzewników Polskich „Problemy cieptownictwa, ogrzewnictwa, wentylacji i klimatyzacji", Warszawa: PZiTS.

Jędrzejewska-Ścibak, T., Sowa, J., Zawada, B.A. (1992). Metodyka poszukiwania racjonalnych rozwiązań technicznych zapewniających wymaganą jakość powietrza wewnętrznego. COW 9.

Jędrzejewska-Ścibak, T., Sowa, J. (2000). Zdrowe powietrze w domu. Warszawa: Wydawnictwo Murator.

JL (2013). Journal of Law item 926. Ordinance of the Minister of Transport, Construction and Maritime Economy of 5 July 2013 amending the regulation on the technical conditions to be met by buildings and their location.

OMI (2002). The Ordinance of the Minister of Infrastructure. W sprawie warunków technicznych, jakim powinny odpowiadać budynki i ich usytuowanie of 12 April (Journal of Laws No 75, item 690) with amendments.

PN-83/B-03430 (with the A3:2000 amendment) Wentylacja w budynkach mieszkalnych, zamieszkania zbiorowego i użyteczności publicznej. Wymagania.

Strzeszewski, M. (2003). Określenie zapotrzebowania na ciepto do wentylacji w przypadku stosowania odzysku ciepta z powietrza wywiewnego, bez nagrzewnic powietrza. Warszawa: Wydawnictwa Instytutu Ogrzewnictwa i Wentylacji Politechniki Warszawskiej. 